\title{
解説)技術と制度のおはなし Technology and Regulation
}

\section{多様な通信・放送手段を連携させた多層的な 災害情報伝達システムの研究開発}

\section{Author}

森下 信 Shin Morishita 総務省総合通信基盤局電波部基幹通信課前重要無線室長

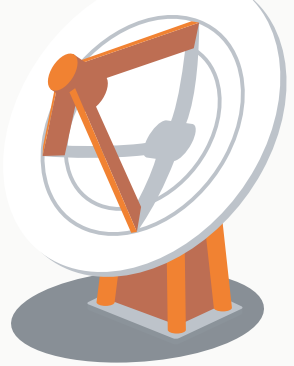

\section{(1) まえがき一本研究開発に着手したきっかけ}

東日本大震災による被害は広範囲に及んでおり，防災 行政無線をはじめとする災害情報を伝達する各手段につ いても，地震そのものによる被害のほか津波による浸水 や流出等により, 設備等の機能停止や倒壊など多大な被 害が生じた。加えて，防災行政無線の放送が聞き取れな いといった，災害情報を地域住民等に迅速かつ確実に伝 達できなかったという問題が指摘された（図 1)。小規模 な災害はもとより，大規模・広域災害の発生時には，地 方自治体（市町村を想定）からその地域住民等に災害に 関する避難情報や警報等を速やかに伝わることが極めて 重要である.このことから，総務省では，災害時（特に 災害発生時）に，より迅速かつより確実な災害情報の伝
達を可能とする技術の確立とその標準化を通じた技術の 普及を目的として，これまで主力であった防災行政無線 のみならず，携帯電話やデジタル放送等，多様な通信・ 放送手段を連携させた多層的な災害情報伝達システムの 技術開発・フィールド実証に取り組むこととした。その 概要を以下に御紹介する。

\section{技術課題と到達目標}

本研究開発では, 前述の多様な通信・放送手段を連携 させた多層的な災害情報伝達システムの技術を確立する に当たり, 新たな技術が必要となる以下の三つの課題に 取り組む(図 2).

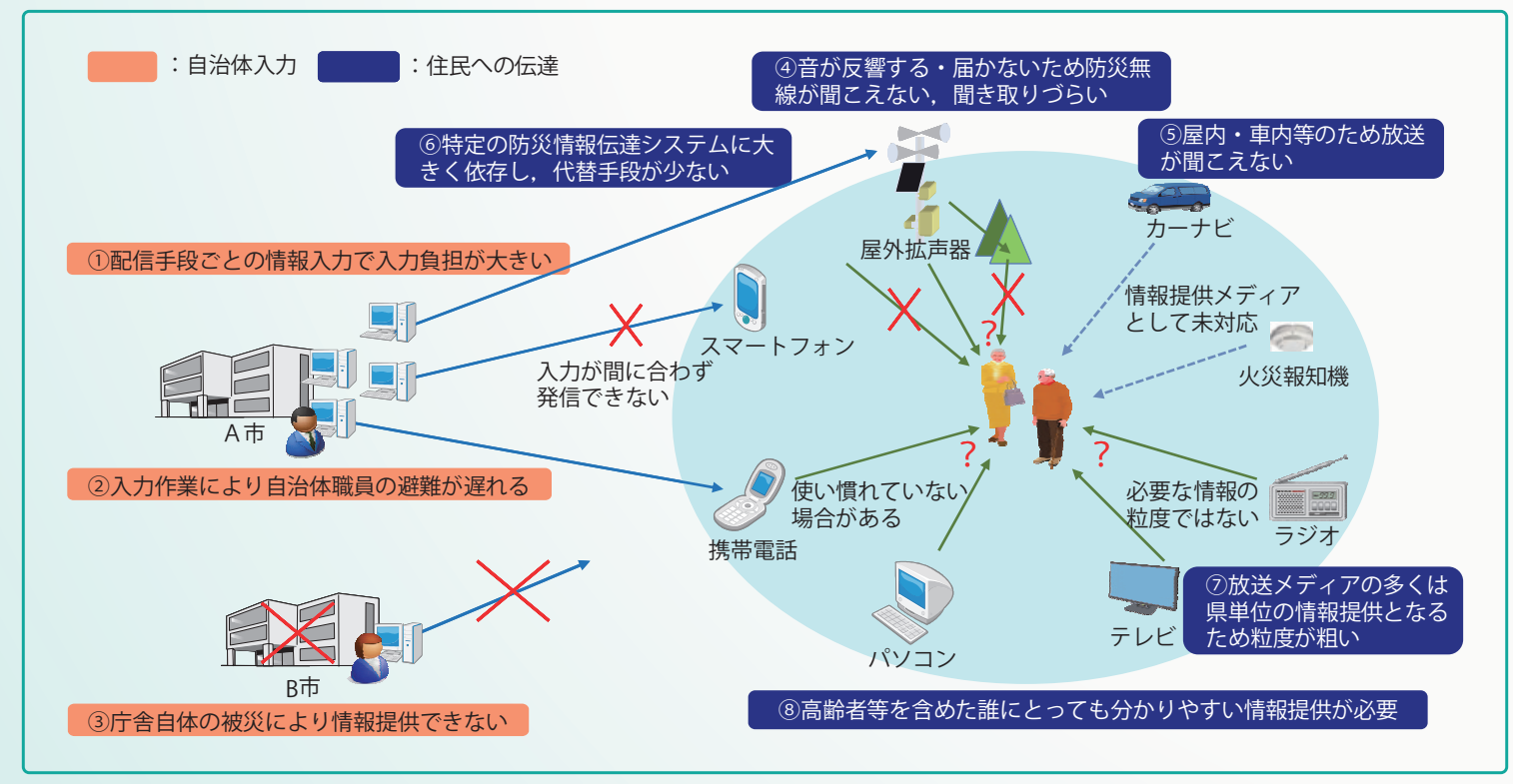

図 1 震災時に発生した情報伝達の問題点 


\section{1 課題 (ア)：配信コンテンツの自動生成技術}

住民への災害情報の一斉同報に利用可能な通信・放送 手段として，防災行政無線以外に，災害情報を対象エリ アに対して一斉配信する電子メールサービス（以下，『緊 急速報メール』という) やデジタル放送等の伝達手段の利 活用が地方自治体等から強く要望されている。これらの 様々な伝達手段に対して災害情報を配信するためには， 各々の伝達手段に応じた文字情報や音声情報，画像・映 像情報等の多様な形式の配信コンテンツを作成する必要 がある。これまでも複数の伝達手段を用いて災害情報を 伝達していた地方自治体は，複数形式のコンテンツ作成 にかかる時間的な手間や操作手順の習得等の負担を強い られてきた。しかしながら，特に緊急性が求められる災 害発生時の運用を想定した場合，地方自治体職員がこれ らの配信コンテンツを手動で個別に作成することは迅速 な情報伝達や職員の避難への妨げとなる。このため, 地 方自治体における災害時の運用性を踏まえ，職員が入力 した災害情報及び外部機関から通知された災害情報を， 伝達手段ごとの形式に自動的に変換し配信コンテンツを 生成することにより，職員の作業負担を軽減し，迅速な 情報提供に資する自動生成技術を開発することとした。

\section{【到達目標】}

通常は，地方自治体職員自ら入力した災害情報に加 えて，外部システムからの災害情報をエリアごとに集約
した上で，職員が個別の伝達手段ごとに災害情報を作成 することとなる，それでは職員の作業量が多くなり，迅 速に情報配信ができない，その代わりに多様な伝達手段 で利用しやすく地域住民が理解しやすい形式の配信コン テンツを自動生成することで, 地方自治体職員による警 報等の災害情報の伝達作業を支援する技術を開発する。

外部システムとしては公共情報 ${ }^{[1]}$ コモンズ及び J-Alert ${ }^{[22}$ を含む 3 以上のシステム, 災害の種類としては津波, 地震 等の 3 以上のシナリオを設定の上, 各々の災害状況に適し た避難情報等を自動配信する技術についても開発を行う.

\section{2 課題 (イ) : 多㮀な通信・放送手段への配信制御技術}

課題（ア）に打いて生成された配信コンテンツ（災害 情報）の伝達手段である緊急速報メールやデジタル放送 等の通信・放送サービス事業者に対して地方自治体から コンテンッを配信する際, データフォーマット及び送信 経路は, 各々異なっている。 そのため, 地方自治体職員 が個別に配信のために操作する必要があるなど災害時の 迅速な運用の妨げとなっている，そこで，地方自治体の 防災業務等の運用性を踏まえた上で，これらの通信・放 送手段の違いを職員が意識することなく，一元的に取り 扱える配信制御技術を開発する必要がある。

\section{【到達目標】}

地方自治体における災害時の運用性を考慮し，通信・

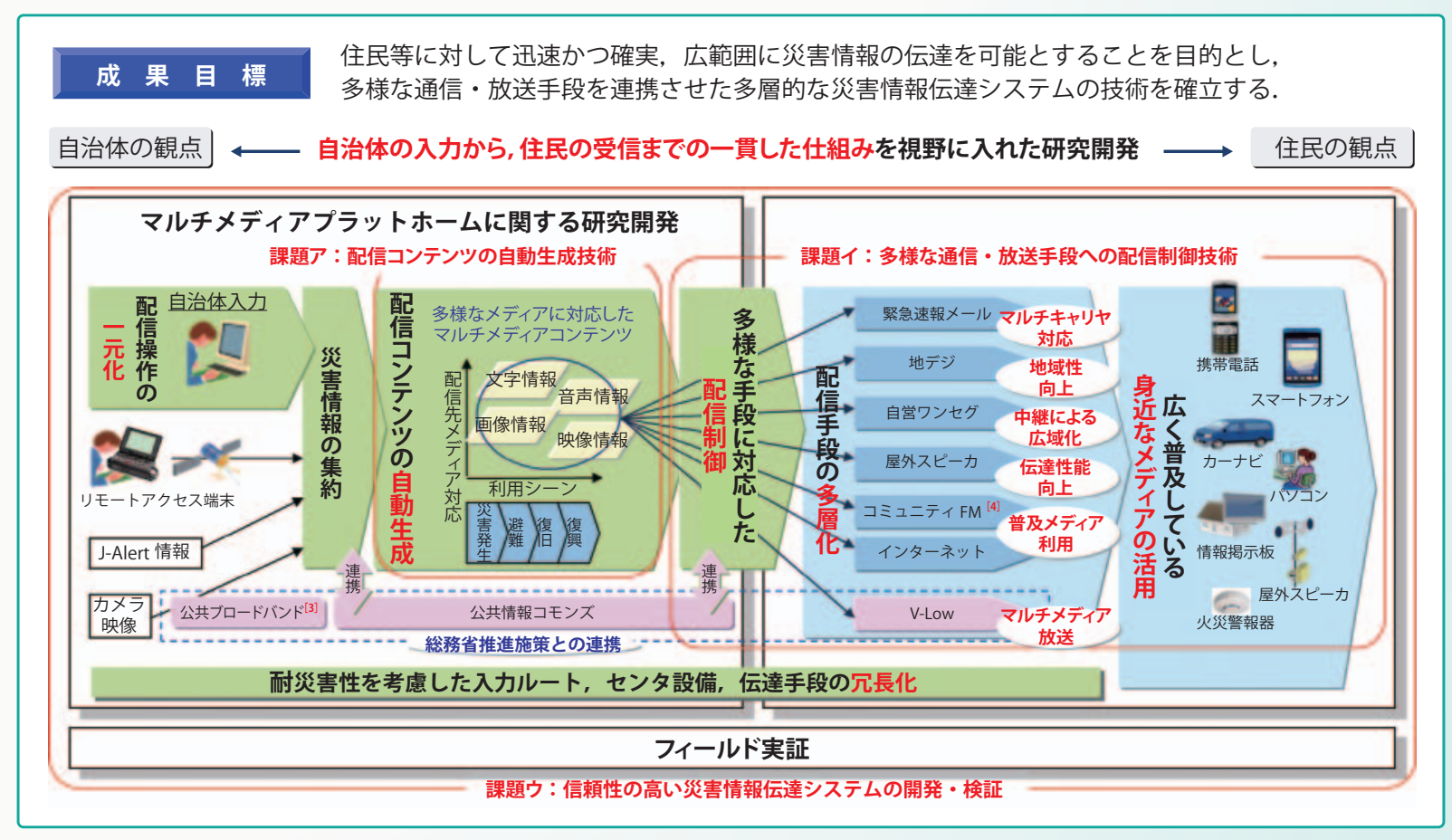

図 2 本研究開発の全体像 
放送手段の違いを意識せずに一元的に配信を行うことが できる技術を開発する，少なくとも緊急速報メールやデ ジタル放送を含む複数のサービスを対象とする.

具体的には，緊急速報メールについては，複数の事業 者が同サービスを提供する場合，職員が 1 回の操作で複 数事業者の緊急速報メールを一括送信できるシステムの 開発を行う。また，地域住民への災害映像等を含めた情 報の確実な伝達のため，デジタル放送を活用した災害情 報配信システムを構築する。

\section{3 課題 (ウ)：信頼性の高い災害情報伝達システムの 構築技術}

東日本大震災のような未曾有の広域災害に直面した 際，システム自体の倒壊，故障や長時間停電等による機 能停止という設備上の課題が存在する．加えて，対応す る職員の安全確保等の運用面の課題もある。災害情報伝 達システムは住民の安全確保のため迅速かつ継続的な運 用が求められることから，システム構築に当たっての設 備面・運用面に関して信頼性の高いシステム構築技術を 開発する必要がある。

\section{【到達目標】}

地方自治体における災害時の運用性等を考慮し，以下 を考慮したシステム構築技術を開発する。

(1) システムの二重化
(2) 地域住民等に災害情報を伝達させる能力の向上

(3) バックアップサイト構築

(4) 隣接地方自治体等からの代替運用

(5) 衛星通信を介したリモートアクセス

（6）地方自治体間での災害情報の共有連携

また，その有効性を人口特性や地理的特性等を考慮し， 人口密集部, 山間部, 海岸部等の 3 か所以上の実地で検 証する。これらの成果について，地方自治体での導入を 前提とした推奨すべきシステム構築技術の一つとして, 多様な通信・放送手段とのインタフェースを標準仕様と してまとめる.

\section{3)・フィールド実証}

本研究開発においては, 東日本大震災の被災地である宮 城県内の地方自治体の協力を得て, フィールド実証の実施 を計画している（図3）。この中で，前述の課題（ア）及び 課題 (イ) に対応するマルチメデイアプラットホーム ${ }^{[5]}$ を, 課題（ウ）に対応するマルチキャリヤ対応緊急速報メール システム，地デジ・自営ワンセグ放送及び V-Low ${ }^{[6]} マ ル$ チメディア放送を活用した災害情報伝達システム，屋外に おける伝達性能を向上させた拡声システム等を，それぞれ 試作することとなっている.

各システム個々に実験することにより，個別システム

個々の技術課題に関する実証に加え，実フィールドでの全体実証を行う．フィールド実証では，被災時に様々な 運用手順に従って災害情報を入力し, 自治体における運用性等を踏まえたシステムの有効性について確認する。

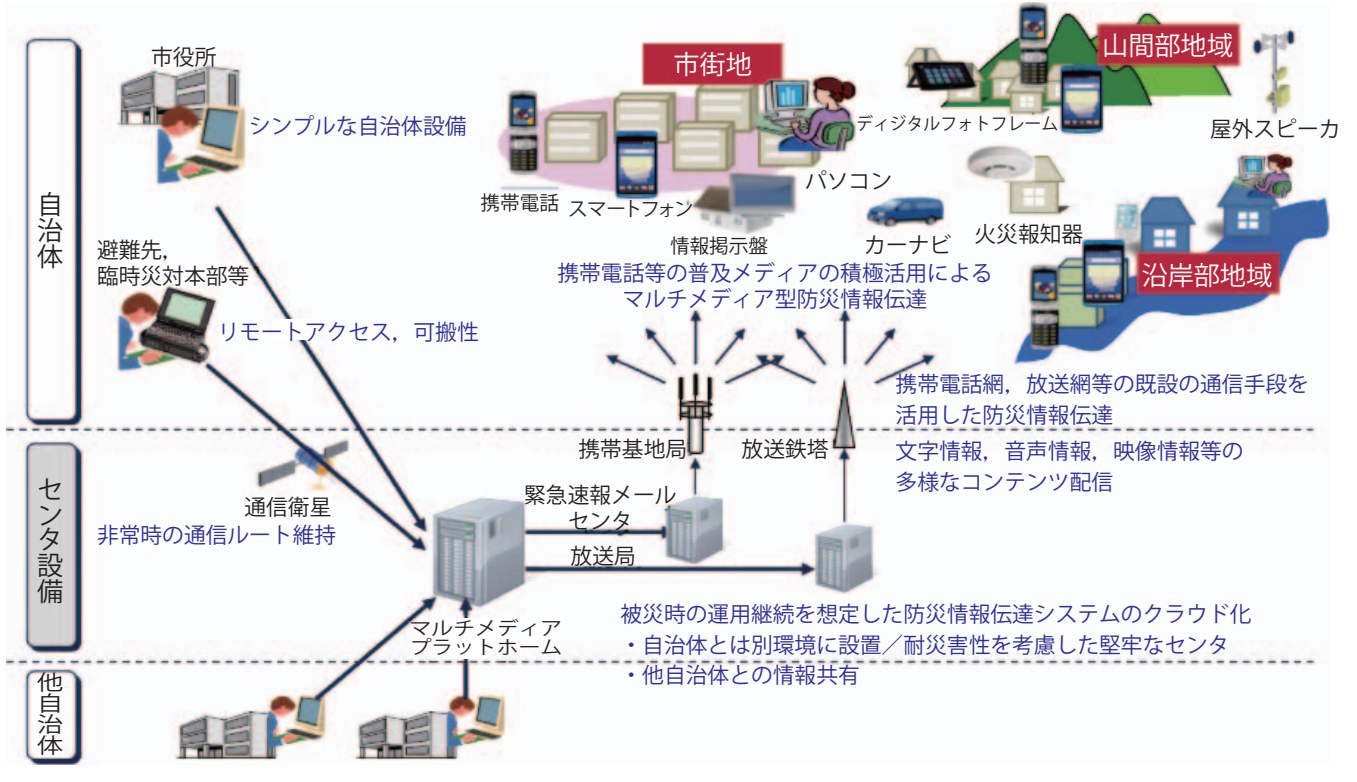

図 3 フィールド実証イメージ 
の性能等を評価し，またシステムを組み合わせて実証実 験を実施することにより，地方自治体による入力（若し くは J-Alert 等の外部システムからの情報入力）から住民 の受信までの一貫した仕組みとしての有効性等の評価を 実施する計画である。このフィールド害証の実施により， 研究室環境では得られない実環境における各システムの 性能評価が得られるとともに，各システムを実際に組み 合わせた複数の伝達手段を得られる環境における総合シ ステムとしての有効性の評価が可能となる。

\section{むすび一本研究開発の効果}

本研究開発は，地方自治体による災害情報入力の迅速 化及び配信制御の一元化及び通信・放送を連携させた情 報伝達手段の多様化を実現することにより，地方自治体 での実用化を見据えた災害情報伝達技術の確立を目的と している. 本研究開発を通じて, より迅速に地域住民等 に重要な災害情報が伝達されること及び一部の手段が被 災し情報伝達ができない場合でも，他の手段を用いてよ り確実に地域住民等に災害情報が伝達されることを実現 する技術の確立を目指している。これにより，特に地震 や津波といった災害の発生時における避難呼びかけ等の 緊急を要する状況において，より多くの人命を救うこと ができる，地方自治体職員がより早急に避難できる，と いった効果の発現を期待している (図 4 参照). 更に，災 害情報を伝達するにとどまらず，将来的には，入力され た災害情報を用いて機器・設備を制御可能とする成果の 発展も期待している。この成果の発展が実現すれば，災 害発生時の避難誘導や交通制御，水門や遮断機の開閉な ど地方自治体が能動的に災害を最小限に食い止める役割 も持たせることができ，地方自治体の災害対応力の高度

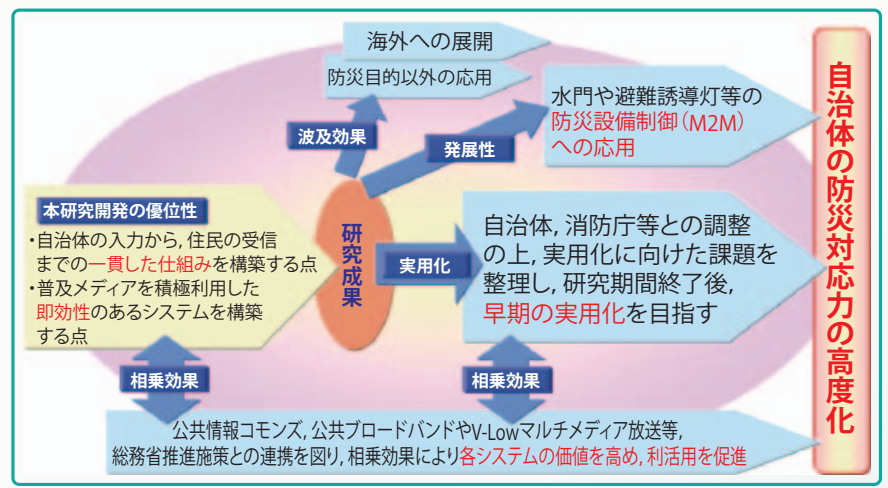

図 4 研究開発により期待される効果
化が期待されるものである.

前述のとおり, 平成 24 年秋には東日本大震災の被災 地域の地方自治体の御協力を得て, 本研究開発を活用し た実証実験を行っていく計画である。また，その結果を 踏まえ, 今年度末までに成果の取りまとめ, 本研究開発 によって確立した技術についての標準仕様の作成等を 行っていく予定である. 総務省においては, その後, 当 該技術の研究成果を踏まえて, 災害情報伝達技術の実用 化，普及推進及び成果の発展等を図っていく所存である. これらの取組みにより, 地方自治体の防災対応力の高度 化の達成を期待するものである.

\section{【用語解説】}

[1] 公共情報コモンズ：地方自治体，ライフライン関連事 業者など安心・安全に関わる公的な情報を発信する「情報 発信者」と, 放送事業者, 新聞社, 通信関連事業者などそ の情報を住民に伝える「情報伝達者」とが，この情報基盤 を共通に利用することによって，地域を越えて全国の情報 伝達者に一斉に配信できる「システム」また「サービス」.

［2］J-Alert：全国瞬時警報システム。弾道ミサイル情報, 津波情報，緊急地震速報等，対処に時間的余裕のない事 態に関する情報を，人工衛星を用いて国（内閣官房・気 象庁から消防庁を経由）から送信し，市区町村の同報系 の防災行政無線等を自動起動することにより，国から住 民まで緊急情報を瞬時に伝達するシステム。

[3] 公共ブロードバンド：地上テレビジョン放送のデイジ タル化により空き周波数となった VHF 带の一部を利用 した，安全・安心な社会の実現のためにブロードバンド 通信が可能な自営通信.

[4]コミュニティ FM：市区町村内の一部の地域において, 地域に密着した情報を提供するために制度化された, FM ラジオ放送.

[5] マルチメディアプラットホーム : 本研究開発で開発対 象となっている，配信コンテンツの自動生成・配信情 報の優先度制御を備えたシステム。

［6］V-Low：従来の地上アナログテレビジョン放送が使用 していた 90〜 $108 \mathrm{MHz}$ の周波数帯. 地上アナログテレ ビジョン放送の終了に伴い，地方ブロック向けマルチメ ディア放送で使用することとされた。

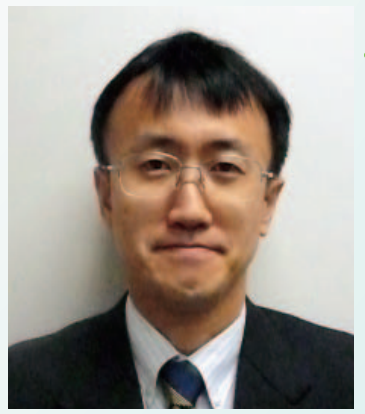

\section{森下 信}

平 6 郵政省 (現, 総務省) 入省以来, 情報通信行政に従事. 平 23-07 総 合通信基盤局電波部基幹通信課重 要無線室長として, 災害時におけ る重要無線通信の確保等を担当. (現在は平 24-08より同局電気通 信事業部電気通信技術システム課 番号企画室長). 